\title{
Upaya Meningkatkan Motivasi Dan Hasil Belajar Siswa pada Materi Menentukan Ide Pokok Paragraf dengan Teknik Membaca Intensif di SD Negeri Bambalo
}

\author{
Asmin A Kandupi \\ SD Negeri Bambalo, Tojo Una Una - Provinsi Sulawesi Tengah \\ Corresponding Author. Email: asminkandupi000@gmail.com
}

\begin{abstract}
This study aims to improve student motivation and learning outcomes in determining the main idea of paragraphs using intensive reading techniques at SD Negeri Bambalo. This research method uses classroom action research conducted in 2 cycles. The research subjects were 9 grade students of SDN Bambalo Semester 1 in the academic year 2020/2021. Data collection techniques in this study used tests and documentation. The data validation used triangulation techniques. The results of this study indicate that the application of an intensive reading technique approach to the material of determining the main idea of paragraphs can increase student motivation and learning outcomes. The class average score increased from 56.99 in the initial study, to 72.88 in the first cycle, and in the second cycle to 81.88 with the level of completeness of learning from 2 students or $22.22 \%$ in the initial conditions to 5 students or $55.55 \%$ in the first cycle and 8 students or $88.89 \%$ in the second cycle. The increase in learning motivation is also getting better, in the initial study there were 2 students or $22.22 \%$ of 9 students, in cycle I, students were complete as seen from the learning motivation of 5 students or $55.55 \%$ of 9 students, and in cycle II, Incomplete seen from the learning motivation of 9 students or $100 \%$ of 9 students. The conclusion is that the application of intensive reading techniques can increase motivation and learning outcomes of fifth grade students of SDN Bambalo Semester 1 in the 2020/2021 academic year.
\end{abstract}

\begin{abstract}
Abstrak: Penelitian ini bertujuan untuk menigkatkan motivasi dan hasil belajar siswa pada materi menentukan ide pokok paragraf dengan teknik membaca intensif di SD Negeri Bambalo. Metode penelitian ini menggunakan penelitian tindakan kelas yang dilakukan sebanyak 2 siklus. Subyek penelitian adalah siswa kelas V SDN Bambalo Semester 1 Tahun Pelajaran 2020/2021 yang berjumlah 9 orang. Teknik pengumpulan data dalam penelitian ini menggunakan tes dan dokumentasi. Validasi data menggunakan teknik triangulasi. Hasil penelitian ini menunjukkan bahwa penerapan pendekatan teknik membaca intensif pada materi menentukan ide pokok paragraf dapat meningkatkan motivasi dan hasil belajar siswa. Nilai rata-rata kelas semakin meningkat dari 56,99 pada studi awal, menjadi 72,88 pada siklus I, dan pada siklus II menjadi 81,88 dengan tingkat ketuntasan belajar dari 2 siswa atau $22,22 \%$ pada kondisi awal menjadi 5 siswa atau 55,55\% pada siklus pertama dan 8 siswa atau $88,89 \%$ pada siklus kedua. Adapun peningkatan motivasi belajar juga semakin membaik, pada studi awal sebanyak 2 siswa atau 22,22\% dari 9 siswa, pada siklus I, siswa tuntas dilihat dari motivasi belajar sebanyak 5 siswa atau 55,55 \% dari 9 siswa, dan pada siklus II, belum tuntas dilihat dari motivasi belajar sebanyak 9 siswa atau 100\% dari 9 siswa. Kesimpulannya adalah penerapan teknik membaca intensif dapat meningkatkan motivasi dan hasil belajar siswa kelas V SDN Bambalo Semester 1 Tahun Pelajaran 2020/2021.
\end{abstract}

How to Cite: Kandupi, A. (2021). Upaya Meningkatkan Motivasi Dan Hasil Belajar Siswa pada Materi Menentukan Ide Pokok Paragraf dengan Teknik Membaca Intensif di SD Negeri Bambalo. Jurnal Paedagogy, 8(2). doi:https://doi.org/10.33394/jp.v8i2.3482

https://doi.org/10.33394/jp.v8i2.3482

This is an open-access article under the CC-BY-SA License.

\author{
Article History \\ Received: 29-01-2021 \\ Revised: 09-03-2021 \\ Published: 04-04-2021
}

\begin{abstract}
Key Words:
Motivation, Learning

Outcomes, Intensive

Reading Techniques.
\end{abstract}

\section{Sejarah Artikel}

Diterima: 29-01-2021

Direvisi: 09-03-2021

Diterbitkan: 04-04-2021

\section{Kata Kunci:}

Motivasi, Hasil Belajar Siswa, Teknik Membaca Intensif. 


\section{Pendahuluan}

Pendidikan merupakan kebutuhan utama dalam pengembangan sumber daya manusia dan masyarakat suatu bangsa. Untuk itu, pendidikan diharapkan mampu membentuk sumber daya manusia yang berkualitas dan mandiri, serta memberi dukungan dan perubahan untuk perkembangan masyarakat, bangsa, dan negara Indonesia. Untuk mencapai pendidikan yang bermutu dan berkualitas lebih baik, maka pemerintah mulai mengembangkan Kurikulum baru yaitu Kurikulum 2013 dengan penyempurnaan pola pikir, penguatan tata kelola Kurikulum, pendalaman dan perluasan materi, penguatan proses pembelajaran, dan penyesuaian beban belajar agar dapat menjamin kesesuaian antara apa yang diinginkan dengan apa yang dihasilkan. Pengembangan Kurikulum menjadi amat penting sejalan dengan kontinuitas kemajuan ilmu pengetahuan, teknologi, dan seni budaya serta perubahan masyarakat pada tataran lokal, nasional, regional, dan global di masa depan.

Beragam kemajuan dan perubahan itu melahirkan tantangan baru di bidang pendidikan agar lebih bisa maju. Karena itu, implementasi Kurikulum 2013 merupakan langkah strategis dalam menghadapi globalisasi dan tuntutan masyarakat Indonesia masa depan. Pengembangan Kurikulum 2013 merupakan langkah lanjutan pengembangan Kurikulum Berbasis Kompetensi yang telah dirintis pada tahun 2004 dan Kurikulum Tingkat Satuan Pendidikan 2006 yang mencakup kompetensi sikap, pengetahuan, dan keterampilan secara terpadu..

Di tingkat SD/MI, kurikulum 2013 menggunakan pendekatan pembelajaran tematik integratif dari kelas I sampai kelas VI. Pembelajaran tematik integratif merupakan pendekatan pembelajaran yang mengintegrasikan berbagai kompetensi dari berbagai mata pelajaran ke dalam berbagai tema. Secara khusus pada mata pelajaran Bahasa Indonesia yang bertujuan untuk memperkuat jati diri anak bangsa. Implementasian Kurikulum 2013 ini, Bahasa Indonesia sangat dihargai dengan banyaknya alokasi waktu yang diberikan. Untuk kelas I dan kelas II SD, mapel Bahasa Indonesia 8 jam seminggu, sedangkan untuk kelas III sampai kelas VI sebanyak 10 jam seminggu. Dengan demikian, posisi mapel Bahasa Indonesia akan menjadi sentral bagi mapel lainnya.

Guru sebagai tenaga pendidik atau pengajar yang telah dibekali seperangkat kemampuan yang dibutuhkan dalam pembelajaran, tentu harus berperan sebagai demonstrator, pengelola kelas, mediator, motivator dan fasilitator yang optimal sehingga pembelajaran yang dilaksanakan akan mencapai tujuan yang ditetapkan. Kenyataan dilapangan menunjukkan bahwa keterampilan dan kemampuan menulis siswa di sekolah dasar masih belum memuaskan. Hal ini disebabkan oleh adanya beberapa hambatan, baik yang bersifat internal maupun eksternal. Hambatan-hambatan tersebut diantaranya adalah hambatan psikologis maupun metodologis. Hambatan psikologis dapat dilihat dari sikap sikap kebanyakan peserta didik yang menganggap pembelajaran menulis sebagai suatu beban dan sulit. Sementara hambatan metodologis dapat dilihat dari penggunaan metode pembelajaran yang cenderung kurang proporsional, dimana antara teori dan praktek masih belum seimbang.

Tujuan pengajaran harus tepat pada sasaran. Banyak faktor yang mendukung keberhasilan pengajaran, diantaranya guru, siswa, sarana dan prasarana, metode dan teknik pembelajaran. Di antara faktor-faktor pendukung keberhasilan pengajaran tersebut yang paling banyak menentukan keberhasilan pengajaran adalah teknik atau cara. Oleh karena itu, guru harus dapat mengkombinasikan teknik pengajaransesuai dengan situasi. Hal ini dilakukan supaya siswa tidak bosan dan PBM tidak terkesan monoton. Walaupun peranan guru sangat dominan dalam pembelajaran tetapi keberhasilan dalam 
melaksanakan suatu pelajaran sebagian besar ditentukan oleh pilihan bahan dan pemakaian metode yang tepat.

Motivasi sangat besar pengaruhnya terhadap belajar, bila guru tidak mampu meningkatkan motivasi maka siswa tidak akan belajar dengan sebaik-baiknya, karena tidak ada daya tarik tersendiri baginya. Siswa segan untuk belajar, siswa tidak memperoleh kepuasan dari pelajaran itu. Bahan pelajaran yang menarik motivasi siswa, lebih mudah dipelajari dan disimpan karena motivasi menambah semangat kegiatan belajar. Motivasi belajar merupakan salah satu aspek psikis yang membantu dan mendorong seseorang untuk mencapai tujuannya (Nurmala, 2020; Nurmiati, 2020; Setiarini 2016; Mahartati 2017, Suarni dkk; 2021).

Permasalahan pembelajaran yang muncul terutama di kelas V SDN Bambalo adalah rendahnya motivasi belajar yang berimplikasi pada rendahnya hasil belajar siswa baik secara individu maupun klasikal. Pada studi awal menunjukkan hasil tes formatif terhadap kemampuan siswa dalam menentukan kalimat kesimpulan (ide pokok) dari berbagai pola paragraf induksi, deduksi masih rendah, hal ini terbukti hanya ada 2 siswa $(22,22 \%)$ yang dinyatakan tuntas dari 9 siswa yang dapat mencapai tingkat penguasaan materi $70 \%$ ke atas atau mendapat nilai di atas KKM sebesar 70 , sedangkan sisanya 7 orang $(77,78 \%)$ belum tuntas dalam belajarnya dengan perolehan nilai di bawah 70. Penjelasan mengenai nila ratarata hasil belajar secara klasikal menunjukkan angka 56,99.

Hasil di atas menunjukkan bahwa siswa belum dapat memahami isi bacaan dan belum dapat menemukan kalimat utama dengan benar. Terlihat dari hasil belajar siswa yang rendah yang diperoleh peneliti pada saat dilaksanakan tes formatif pada kegiatan prasiklus. Hal tersebut terjadi dikarenakan guru kurang bervariasi menggunakan model pembelajaran, siswa kurang memahami cara menemukan kalimat utama, guru jarang melakukan tanya jawab kepada siswa pada materi membaca. Untuk mengatasi masalah di atas, diperlukan suatu upaya untuk memperbaiki kelemahan proses pembelajaran yaitu dengan menerapkan teknik membaca intensif.

Membaca intensif dapat diartikan sebagai suatu kegiatan membaca yang dilakukan seseorang secara cermat guna menemukan suatu informasi inti dari bahan bacaan. Membaca intensif pada hakekatnya memerlukan teks yang panjangnya \pm 300 patah kata (yang dapat dibaca dalam jangka waktu 2 menit dengan kecepatan kira-kira 5 (lima) patah kata dalam satu detik). Membaca intensif dilakukan untuk mengembangkan keterampilan membaca secara detail dengan menekankan pada pemahaman kata, kalimat, pengembangan kosakata, dan juga pemahaman keseluruhan isi wacana serta untuk menemukan ide-ide pokok atau kalimat utama pada tiap paragraf (Tarigan, 2008, Soedarso, 2004; Wagiran \& Doyin 2005). Dalam pembelajaran membaca intensif, siswa dituntut untuk dapat memahami isi bacaan dan menemukan ide-ide pokok atau kalimat utama yang terdapat pada tiap paragraf. Dalam hal ini, guru juga mempunyai peranan yang penting untuk dapat membimbing siswa dalam menemukan kalimat utama sehingga dapat tercapai tujuan pembelajaran yang telah ditetapkan (Rahim 2008; Resmini, 2009).

Adapun tujuan dalam penelitian ini adalah untuk menigkatkan motivasi dan hasil belajar siswa pada materi menentukan ide pokok paragraf dengan teknik membaca intensif di SD Negeri Bambalo.

\section{Metode Penelitian}

Penelitian ini menggunakan metode penelitian tindakan kelas (PTK). Penelitian tindakan kelas ini merupakan tindakan yang bertujuan untuk meningkatkan motivasi dan 
hasil belajar siswa pada pembelajaran bahasa Indonesia materi menentukan ide pokok paragraf. Tindakan yang dilakukan adalah menerapkan teknik membaca intensif yang dilaksanakan dalam 2 siklus tindakan. Pendekatan yang digunakan dalam penelitian ini adalah adalah pendekatan deskriptif. Subjek penelitian dalam penelitian ini adalah siswa kelas V SDN Bambalo Semester 1 Tahun Pelajaran 2020/2021 dengan jumlah siswa sebanyak 9 siswa terdiri dari siswa laki-laki 6 siswa dan perempuan 3 siswa. Sumber data yang digunakan dalam penelitian ini adalah sumber data primer dan sumber data sekunder. Sumber data primer adalah siswa kelas V SDN Bambalo Semesester 1 Tahun Pelajaran 2020/2021. Adapun sumber data sekunder berasal dari sumber data yang berasal dan pihak yang masih ada kaitannya dengan siswa, akan tetapi tidak secara langsung mengetahui keberadaan siswa atau berhubungan langsung dengan siswa, misalnya obsever dan kepala sekolah. Dalam penelitian ini, data primer yang digunakan adalah nilai hasil belajar. Ada tiga macam nilai yang diambil dari subjek penelitian yaitu kondisi awal, pretes dan nilai akhir siklus. Dari data-data tersebut akan dipergunakan untuk menentukan terjadinya peningkatan hasil belajar adalah nilai kondisi awal dan nilai akhir siklus. Teknik pengumpulan data penelitian ini menggunakan observasi, lembar dokumentasi, dan tes. Sedangkan teknik analisis data penelitian ini menggunakan analisis deskriptif.

\section{Hasil Penelitian dan Pembahasan Deskripsi Siklus I \\ Tahap Perencanaan}

Berdasarkan rumusan hipotesis yang telah dibuat, peneliti menyiapkan dan menetapkan Rencana Perbaikan Pembelajaran beserta skenario tindakan yang akan dilaksanakan pada pertemuan pertama dan kedua. Skenario tindakan mencakup langkahlangkah yang akan dilakukan oleh guru dan siswa dalam kegiatan tindakan atau perbaikan. Terkait dengan revisi rencana perbaikan pembelajaran, peneliti menyiapkan berbagai alat dan bahan yang diperlukan, meliputi : lembar kerja siswa, lembar tes formatif dan lembar observasi, naskah bacaan dengan judul dan variasi yang berbeda-benda. Kemudian bersamasama dengan teman sejawat (observer) menyepakati fokus observasi dan kriteria yang akan digunakan dalam dua pertemuan yang akan dilaksanakan. Sebelum dilaksanakan, peneliti bersama observer mengadakan simulasi terlebih dahulu terhadap Rencana Perbaikan Pembelajaran beserta skenario tindakan, dan naskah bacaan yang akan digunakan pada saat pelaksanaan kegiatan proses perbaikan pembelajaran dengan tujuan untuk menghindari terjadinya kegagalan dalam tahap pelaksanaan, terutama pada pemakaian naskah bacaan untuk pelaksanaan kegiatan membaca intensif untuk menentukan ide pokok naskah bacaan.

\section{Tahap Pelaksanaan Tindakan}

Setelah bel berbunyi anak-anak masuk ke kelas dengan tertib, lalu berdoa dan peneliti mengabsen kehadiran siswa. Peneliti mempersiapkan alat pembelajaran yang akan diperlukan. Sebelum kegiatan belajar mengajar dimulai, peneliti memberikan apersepsi terlebih dahulu. Pada kegiatan inti pertemuan pertama, peneliti mengawali dengan peneliti menjelaskan pengertian gagasan utama teks. Untuk meningkatkan pemahaman, peneliti kemudian menjelaskan cara menentukan gagasan utama teks. Pikiran pokok bacaan ada dalam setiap paragraf. Jadi, dalam sebuah paragraf itu ada kalimat utama atau pikiran pokok dan ada pikiran penjelas. Letak ide pokok itu ada yang di awal atau di akhir paragraf. Perhatikan contoh paragraf berikut!", jelas peneliti. 
Raden Saleh lahir pada tahun 1807. Raden Saleh dilahirkan di lingkungan bangsawan Jawa. Pada masa itu, para bangsawan Jawa sangat dekat dengan pemerintah Belanda. Sejak usia 10 lahun, ia sudah bergaul dengan orang Belanda. Alasannya sang paman yang menjadi Bupati Semarang, dekat dengan pejabat Belanda.

Kalimat utama atau ide pokok dari paragraf tersebut adalah:

\section{Raden Saleh dilahirkan di lingkungan bangsawan Jawa.}

Setelah memberikan penjelasan tentang materi teks bacaan, peneliti kemudian meminta salah seorang anak untuk membacakan sebuah teks bacaan, siswa lain memperhatikan dan mendengarkan dengan seksama. Setelah selesai pembacaan teks bacaan, peneliti memberikan pujian kepada anak yang telah membaca teks bacaan tersebut. Untuk meningkatkan daya serap dan pemahaman siswa terhadap materi pembelajaran, peneliti menyajikan beberapa contoh teks bacaan yang berhubungan dengan materi pembelajaran. Berdasarkan teks bacaan di atas, peneliti menjelaskan cara menentukan pokok pikirannya, yaitu menentukan gagasan utama teks dalam setiap paragraf untuk menentukan pokok pikiran dalam paragraf tersebut. Setelah selesai memberikan penjelasan, guru meminta siswa untuk mencari sendiri gagasan utama teks dalam bacaan yang disajikan. Setelah dirasakan cukup peneliti peneliti meminta semua siswa mengumpulkan hasil kerjanya, dilanjutkan menulis kesimpulan akhir kegiatan.

Pada pertemuan kedua, seperti halnya pertemuan pertama, pada pertemua yang kedua pada kegiatan awal siswa berbaris masuk kelas, memberi salam dan peneliti menjawab salam. Peneliti memeriksa kehadiran siswa serta mengatur tempat duduk siswa. Sebagai apersepsi peneliti melakukan tanya jawab. "Anak-anak, masih ingatkah kalian pada pelajaran yang kemarin ?". tanya peneliti. Serempak siswa menjawab, "Masih, Ibu Guru !". "Baiklah, "Berarti kalian benar-benar belajar tadi malam, Ibu Guru bangga pada kalian", puji peneliti untuk memberikan motivasi pada para siswa. Sebelum melaksanakan kegiatan inti pembelajaran, peneliti kembali menjelaskan tentang cara menentukan pokok pikiran. "Anakanak, dalam sebuah paragraf terdapat kalimat utama (pokok pikiran) dan kalimat penjelas. Letak pokok pikiran ada yang di awal, di tengah, atau di akhir paragraf. Perhatikan contoh paragraf berikut. Setelah itu, kamu dapat menemukan pikiran atau gagasan pokok suatu bacaan dengan membaca intensif", jelas peneliti.

Bagi Anda penyuka olahraga selancar, Pantai Cimaja, Sukabuml, Jawa Barat, dapat menjadl pillhan tempat yang pas untuk menyalurkan hobi Anda. Selain lokasinya dekat dengan Jakarta, kualitas ombak yang ditawarkan di pantai ini sesuai dengan standar olahraga selancar.

Sumber: Medie Indonesia

Kalimat utama atau pikiran utama pada bacaan di atas adalah:

Bagi Anda penyuka olahraga selancar, Pantai Cimaja, Sukabumi, Jawa Barat, dapat menjadi pilihan tempat yang pas untuk menyalurkan hobi Anda. 
Setelah memberikan penjelasan tentang materi teks bacaan, dan mengulang penjelasan tentang cara mencari ide pokok pada teks bacaan tersebut, peneliti kemudian meminta salah seorang anak untuk membacakan sebuah teks bacaan berjudul "Lomba Kebersihan Kota?", siswa lain memperhatikan dan mendengarkan dengan seksama.

\section{Lomba Kebersihan Kelas}

Hari ini hari ulang tahun sekclah. Untuk memperingati hari ulang tahun sckolah, diadakan lomba kebersithan antarkclas, yaitu kelas satu sampai kelas enam. Anak-anak menyambut dengan gembira.

Mereha semua ingin menjadi pentenang dalam lombo kebersihun kelas tersebut. Pagi-pagi sekali anak-anak sudah datang ke sekolah. Ada yong membaza sapu, kemoceng, dan alat kebersihan lainnya. Selain itu ada anakanak yang membawa tanaman untuk ditanam di sekolah.

Pukul 07.00 bel betbunyi. Anak-anak masuk ke kelas masing-masing. Dengan bimbingan dari bapak dan ibu guru, anak-anak mulai membersihkan kelas. Mereka bekerja sama agar ruang kelasnya menjadi yang paling betsih dan rapi. Tidak ada yang mengeluh atau berpangku tangan.

Ruang kelas pun dihiasi dengan berbagai macam hiasan. Ada balon dan kerlas wurna-warni. Keias pun menjaudi lebilh meriuh dari huari biasanya. Selelaht riang kelas selesai dibersihkan, anak-anak mulai menanam aneka pohon di halaman sekolah Mereka berharap halaman sekolah menjadi lebih tedwh dan asri.

Anak-anak riang gembirc. Mereka saling bekerja sama dan saling membntu. Kini ruang kelas dan halaman sekolah menjadi lebih indah dan asri.

Setelah selesai pembacaan teks bacaan, peneliti memberikan pujian kepada anak yang telah membaca teks bacaan tersebut. Kegiatan selanjutnya adalah menyajikan teks bacaan tersebut untuk dikerjakan dengan menggunakan lembar kerja siswa yang telah dipersiapkan, dan sebagai penugasan pembelajaran, peneliti meminta para siswa untuk menentukan ide pokok dari teks bacaan tersebut. Peneliti kembali menjelaskan tentang cara menentukan ide pokok pada bacaan di atas. "Anak-anak, coba kalian tuliskan sebuah teks bacaan berdasarkan gambar di atas", perintah peneliti. Para siswa kemudian memperhatikan gambar yang ditempel di papan tulis dengan seksama dan mulai menulis teks bacaan berdasarkan gambar tersebut. Peneliti menjelaskan bahwa letak ide pokok biasanya Letak ide pokok itu ada yang di awal atau di akhir paragraf. Sebagai contoh Hari ini hari ulang tahun sekolah. Untuk memperingati hari ulang tahun sekolah, diadakan lomba kebersihan antar kelas, yaitu kelas I sampai kelas VI. Anak-anak menyambut dengan gembira. Maka ide pokok dari paragraf tersebut adalah: hari ulang tahun sekolah. Kegiatan selanjutnya, siswa diminta secara lisan menemukan ide pokok dalam bacaan di atas secara lisan dan bergantian oleh beberapa siswa. Setelah dirasakan cukup memberikan penjelasan, peneliti peneliti meminta semua siswa mencari ide pokok pada setiap paragrafnya dengan mengerjakan lembar kerja siswa. Setelah selesai mengerjakan lembar kerja siswa, para siswa diminta mengumpulkan hasil kerjanya. Peneliti mengambil beberapa hasil kerja siswa secara acak untuk dibacakan di depan kelas, dan dilanjutkan dengan diskusi tentang ide pokok teks bacaan yang dibacakan, dilanjutkan menulis kesimpulan akhir kegiatan sekaligus menutup kegiatan pertemuan kedua. Di akhir pembelajaran peneliti membagikan soal tes formatif kepada siswa untuk dikerjakan. Kemudian dikumpulkan dan dinilai untuk merefleksi tindakan pembelajaran selanjutnya 
apakah sudah berhasil atau sebaliknya. Pada siklus pertama ini dalam tahap pelaksanaan sudah menunjukkan adanya peningkatan hasil belajar siswa. Hal tersebut dapat dilihat pada tabel berikut ini :

Tabel 1. Rekapitulasi Nilai Tes Formatif Pembelajaran Bahasa Indonesia pada Siklus I

\begin{tabular}{|c|c|c|c|c|c|c|c|}
\hline \multirow[b]{2}{*}{ No } & \multirow{2}{*}{$\begin{array}{c}\text { Rentang } \\
\quad \text { Nilai }\end{array}$} & \multirow{2}{*}{$\begin{array}{c}\text { Jumlah } \\
\text { Siswa }\end{array}$} & \multicolumn{4}{|c|}{ Ketuntasan } & \multirow[b]{2}{*}{ Ket } \\
\hline & & & Tuntas & $\%$ & $\begin{array}{c}\text { Blm } \\
\text { Tuntas }\end{array}$ & $\%$ & \\
\hline 1 & $<=40$ & 0 & & & & & \\
\hline 2 & $50-59$ & 1 & & & 1 & 11,11 & \\
\hline 3 & $60-69$ & 3 & & & 3 & 33,34 & \\
\hline 4 & $70-79$ & 2 & 2 & 22,22 & & & \\
\hline 5 & $80-89$ & 2 & 2 & 22,22 & & & \\
\hline 6 & $>=90$ & 1 & 1 & 11,11 & & & \\
\hline \multicolumn{2}{|c|}{ Jumlah } & 9 & 5 & 55,55 & 8 & 44,45 & \\
\hline \multicolumn{2}{|c|}{ Nilai Tertinggi } & \multicolumn{6}{|c|}{90} \\
\hline \multicolumn{2}{|c|}{ Nilai Terrendah } & \multicolumn{6}{|c|}{56} \\
\hline \multicolumn{2}{|c|}{ Nilai Rata-rata } & \multicolumn{6}{|c|}{72,88} \\
\hline \multicolumn{2}{|c|}{ Ketuntasan } & \multicolumn{6}{|c|}{$\mathbf{5 5 , 5 5}$} \\
\hline
\end{tabular}

Dari tabel sebagaimana dijelaskan di atas dapat diterangkan bahwa nilai rata-rata hasil belajar pada pelaksanaan perbaikan pembelajaran siklus pertama sebesar 78,88 . Jumlah siswa yang tuntas belajarnya sebanyak 5 siswa atau sebesar 55,55\%. Jumlah siswa yang belum tuntas belajarnya sebanyak 4 siswa atau sebesar 44,45\%. Dari penjelasan sebagaimana tersebut di atas dapat disimpulkan bahwa hasil nilai tes formatif mengalami peningkatan dari kondisi awal, karena pada sebelum perbaikan siswa tuntas 2 siswa $(22,22 \%)$ meningkat menjadi 5 siswa $(55,55 \%)$ atau meningkat sebanyak 3 siswa $(33,33 \%)$.

\section{Observasi}

Observer melakukan observasi membantu peneliti terhadap peneliti yang sedang melaksanakan kegiatan pembelajaran. Observer menggunakan lembar observasi yang telah disediakan dan pengamatan ini berlangsung dari awal hingga akhir pembelajaran. Hasil observasi yang dilakukan terhadap peningkatan motivasi belajar siswa menunjukkan bahwa belum semua siswa dapat memahami konsep pembelajaran karena kurangnya pemahaman serta motivasi siswa terhadap materi pembelajaran yang disampaikan.

Penjelasan mengenai aspek motivasi belajar yang diamati adalah kuatnya kemauan untuk berbuat, jumlah waktu yang disediakan untuk belajar, kerelaan meninggalkan kewajiban atau tugas yang lain, ketekunan dalam mengerjakan tugas, ulet menghadapi kesulitan (tidak lekas putus asa, menunjukkan minat terhadap bermacam- macam masalah orang, lebih senang bekerja mandiri, dapat mempertahankan pendapatnya, cepat bosan pada tugas-tugas rutin (Sardiman, 2001). Kegiatan pengamatan ini dilakukan oleh observer selama kegiatan perbaikan pembelajaran berlangsung dengan menggunakan format observasi yang telah dipersiapkan. Hasil observasi pada pelaksanaan perbaikan pembelajaran pada siklus I sebagaimana tabel di bawah ini :

Tabel 2. Rekapitulasi Hasil Observasi Peningkatan Motivasi Siswa Pembelajaran Bahasa Indonesia Pada Siklus I

\begin{tabular}{c|cccc}
\hline No & Rentang Nilai & Jumlah & Persentase & Ket \\
\hline 1 & $90-100$ & 1 & 11,11 & $\mathrm{~T}$ \\
2 & $80-89$ & 2 & 22,22 & $\mathrm{~T}$ \\
\hline
\end{tabular}




\begin{tabular}{c|cccc}
\hline 3 & $70-79$ & 2 & 22,22 & $\mathrm{~T}$ \\
4 & $60-69$ & 3 & 33,33 & BT \\
5 & $<=50$ & 1 & 11,11 & BT \\
\hline
\end{tabular}

Dari tabel di atas dapat disimpulkan bahwa dari 9 siswa terdapat 5 orang yang tuntas belajarnya $(55,55 \%)$ dilihat dari motivasi belajarnya, sedangkan 4 siswa $(44,45 \%)$ belum tuntas dilihat dari motivasi belajarnya. Melihat hasil di atas maka peneliti bersama-sama dengan observer sepakat untuk melaksanakan perbaikan pembelajaran pada siklus II dengan harapan pada siklus II motivasi belajar siswa dapat mencapai perolehan di atas $85 \%$ sesuai dengan kriteria keberhasilan yang telah ditetapkan.

\section{Refleksi}

Pengukuran tingkat keberhasilan disesuaikan dengan kriteria keberhasilan yang telah ditentukan. Hasil pengukuran tersebut menunjukkan bahwa keberhasilan upaya belum sesuai dengan kriteria keberhasilan. Dari kenyataan temuan pada saat pelaksanaan siklus pertama, maka peneliti bersama-sama dengan observer memutuskan untuk mengadakan perbaikan pada siklus kedua dengan menerapkan :

1) Menfokuskan pada kegiatan kelompok pada sesi membaca intensif.

2) Siswa menentukan sendiri kelompoknya berdasarkan faktor-faktor kedekatan antar anggota dalam kelompoknya, misalnya kedekatan pertemanan dan kedekatan lokasi tempat tinggal.

3) Keanggotaan siswa tiap kelompok kerja semakin diperkecil sehingga diharapkan dapat meningkatkan keefektifan pembelajaran.

4) Memperbanyak fasilitas referensi buku sumber untuk mengembangkan materi pembelajaran misalnya dengan meminjam buku-buku yang relevan dengan materi pembelajaran di perpustakaan sekolah dan mempersilahkan siswa untuk bebas

\section{Deskripsi Siklus II} memilih sendiri buku-buku tersebut sesuai dengan bacaan yang dikuasainya.

\section{Tahap Perencanaan}

Berdasarkan hasil refleksi dari siklus pertama, peneliti merevisi Rencana Perbaikan Pembelajaran beserta skenario tindakan. Terkait dengan revisi rencana perbaikan pembelajaran, peneliti menyiapkan berbagai alat dan bahan yang diperlukan, meliputi : lembar kerja siswa, lembar tes formatif dan lembar observasi, naskah-naskah bacaan yang bervariasi baik dari judul maupun jumlah paragraf pada bacaan tersebut. Setelah semua komponen yang diperlukan lengkap, peneliti bersama teman sejawat mensimulasikan langkah-langkah perbaikan pembelajaran yang dilaksanakan dalam dua kali pertemuan. Kemudian bersama-sama dengan teman sejawat (observer) menyepakati fokus observasi dan kriteria yang akan digunakan dalam dua pertemuan yang akan dilaksanakan. Sebelum dilaksanakan, peneliti bersama observer mengadakan simulasi terhadap RPP dan perangkat pembelajaran termasuk peraga naskah bacaan terlebih dahulu untuk menghindari terjadinya kegagalan dalam tahap pelaksanaan kegiatan pembelajaran berlangsung.

\section{Tahap Pelaksanaan Tindakan}

Setelah siswa selesai berdoa dan menunjukkan buku pelajaran, peneliti mengkondisikan siswa untuk siap mengikuti pembelajaran. Kemudian peneliti menyampaikan tujuan pembelajaran yang akan dilaksanakan. Untuk menarik perhatian siswa, peneliti menunjukkan beberapa buku referensi yang bisa digunakan untuk mengembangkan materi pembelajaran. Untuk membangkitkan semangat belajar siswa peneliti mengadakan kegiatan apersepsi peneliti melakukan tanya jawab. "Anak-anak, apakah kaliam masih ingat pelajaran kemarin 
?", tanya peneliti. Salah satu siswa menjawab, "Ingat, Ibu Guru !". "Coba sebutkan materi apa yang kita bahas ?", tanya peneliti lagi. Siswa tersebut menjawab, "Menentukan gagasan utama teks dengan membaca intensif, Ibu Guru !". "Ya, betul, kalian memang anak yang rajin belajar", puji peneliti. "Nah, apakah kalian sudah siap untuk memasuki kegiatan inti pembelajaran?", tanya peneliti. Serempak siswa menjawab, "Siap, Ibu Guru!".

Pada kegiatan inti pertemuan kedua, peneliti mengawali dengan peneliti menjelaskan pengertian teks bacaan, dan cara menentukan gagasan utama teks dari teks bacaan tersebut. Sebelum melaksanakan kegiatan inti pembelajaran, peneliti kembali menjelaskan tentang cara menentukan pokok pikiran. "Anak-anak, dalam sebuah paragraf terdapat kalimat utama (pokok pikiran) dan kalimat penjelas. Letak pokok pikiran ada yang di awal, di tengah, atau di akhir paragraf. Perhatikan contoh paragraf berikut. Setelah itu, kamu dapat menemukan pikiran atau gagasan pokok suatu bacaan dengan membaca intensif", jelas peneliti.

Setelah memberikan penjelasan tentang materi teks bacaan, dan mengulang penjelasan tentang cara mencari ide pokok pada teks bacaan tersebut, peneliti kemudian meminta salah seorang anak untuk membacakan sebuah teks bacaan berjudul "Wilayah Jakarta Tergenang?", siswa lain memperhatikan dan mendengarkan dengan seksama. Setelah selesai pembacaan teks bacaan, peneliti memberikan pujian kepada anak yang telah membaca teks bacaan tersebut. Kegiatan selanjutnya adalah menyajikan teks bacaan tersebut untuk dikerjakan dengan menggunakan lembar kerja siswa yang telah dipersiapkan, dan sebagai penugasan pembelajaran, peneliti meminta para siswa untuk menentukan ide pokok dari teks bacaan tersebut

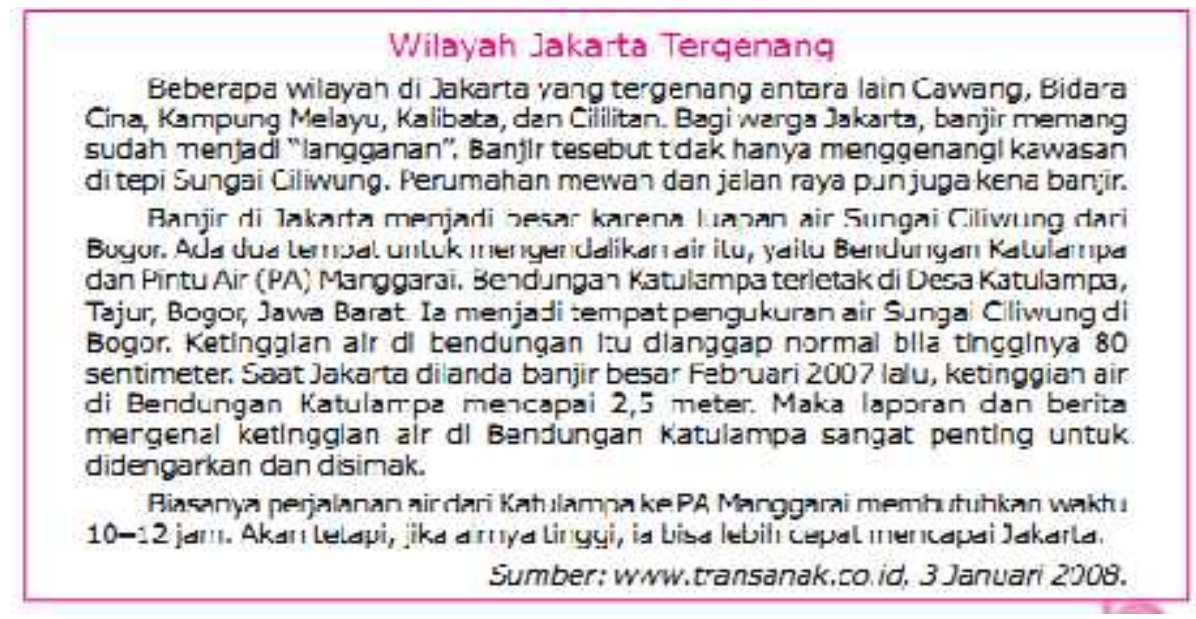

"Anak-anak, coba kalian tuliskan ide pokok dari teks bacaan di atas", perintah peneliti. Para siswa kemudian memperhatikan teks bacaan yang ditempel di papan tulis dengan seksama dan mulai menulis ide pokok teks bacaan berdasarkan teks bacaan tersebut dalam lembar kerja siswa yang sudah disiapkan. Setelah dirasakan cukup peneliti peneliti meminta semua siswa mengumpulkan hasil kerjanya. Peneliti mengambil beberapa hasil kerja siswa secara acak untuk dibacakan di depan kelas, dan dilanjutkan dengan diskusi tentang teks bacaan yang dibacakan, dilanjutkan menulis kesimpulan akhir kegiatan dan sekaligus untuk mengakhiri pelaksanaan pertemuan pertama pada siklus kedua.

Pada pertemuan kedua, seperti halnya pertemuan pertama, pada pertemua yang kedua pada kegiatan awal siswa berbaris masuk kelas, memberi salam dan peneliti menjawab salam. Peneliti memeriksa kehadiran siswa serta mengatur tempat duduk siswa. Sebagai apersepsi peneliti melakukan tanya jawab. "Anak-anak, masih ingatkah kalian pada pelajaran yang kemarin ?". tanya peneliti. Serempak siswa menjawab, "Masih, Ibu Guru, kemarin membahas 
gagasan utama teks teks bacaan", jawab salah seorang siswa. "Ibu Guru bangga pada kalian", puji peneliti untuk memberikan motivasi pada para siswa.

Pada kegiatan inti pertemuan kedua, peneliti mengulang kegiatan sebagaimana pertemuan pertama, yaitu diawali dengan peneliti menjelaskan cara menentukan ide pokok berdasarkan sebuah teks bacaan. "Anak-anak, pada pembelajaran kemarin, kalian telah menuliskan ide pokok dari teks bacaan yang disajikan, sekarang Ibu Guru minta kalian membacakan hasil kerja kalian berupa penulisan ide pokok dari teks bacaan yang kalian tulis tersebut di depan kelas !", perintah peneliti. Beberapa orang siswa membacakan hasil kerjanya . Guru berperan sebagai pengambil kesimpulan.

Setelah semua siswa membacakan teks bacaannya, peneliti memimpin jalannya diskusi kelas. Siswa aktif bertanya mengenai teknik dan cara menentukan ide pokok yang terkandung dalam setiap paragraf pada teks bacaan. Guru melempar pertanyaan itu kembali ke siswa. Beberapa orang siswa ditunjuk untuk menjawab. Guru menengahi dan menarik kesimpulan dari jawaban para siswa tersebut. Di akhir pembelajaran peneliti membagikan soal tes formatif kepada siswa untuk dikerjakan. Kemudian dikumpulkan dan dinilai untuk merefleksi tindakan pembelajaran selanjutnya. Peneliti tidak lupa memberikan saran untuk selalu belajar agar penguasaan materi pembelajaran dapat lebih meningkat dan mempersiapkan pelaksanaan tes formatif akhir siklus kedua. Setelah dirasakan cukup peneliti peneliti meminta semua siswa mengumpulkan hasil kerjanya. Peneliti mengambil beberapa hasil kerja siswa secara acak untuk dibacakan di depan kelas, dan dilanjutkan dengan diskusi tentang gagasan utama teks dari teks bacaan yang dibacakan, dilanjutkan menulis kesimpulan akhir kegiatan dan sekaligus untuk mengakhiri pelaksanaan pertemuan ketiga pada siklus kedua. Pada siklus kedua ini dalam tahap pelaksanaan sudah menunjukkan adanya peningkatan hasil belajar siswa. Hal tersebut dapat dilihat pada tabel berikut ini :

Tabel 3. Rekapitulasi Nilai Tes Formatif Pembelajaran pada Siklus II

\begin{tabular}{|c|c|c|c|c|c|c|c|}
\hline \multirow[b]{2}{*}{ No } & \multirow{2}{*}{$\begin{array}{c}\text { Rentang } \\
\text { Nilai }\end{array}$} & \multirow{2}{*}{$\begin{array}{c}\text { Jumlah } \\
\text { Siswa }\end{array}$} & \multicolumn{4}{|c|}{ Ketuntasan } & \multirow[b]{2}{*}{ Ket } \\
\hline & & & Tuntas & $\%$ & $\begin{array}{c}\text { Blm } \\
\text { Tuntas }\end{array}$ & $\%$ & \\
\hline 1 & $<=40$ & 0 & & & & & \\
\hline 2 & $50-59$ & 0 & & & 0 & 0,00 & \\
\hline 3 & $60-69$ & 1 & & & 1 & 11,11 & \\
\hline 4 & $70-79$ & 3 & 3 & 33,33 & & & \\
\hline 5 & $80-89$ & 3 & 3 & 33,33 & & & \\
\hline 6 & $>=90$ & 2 & 2 & 22,22 & & & \\
\hline \multicolumn{2}{|c|}{ Jumlah } & 9 & 8 & 88,89 & 1 & 11,11 & \\
\hline \multicolumn{2}{|c|}{ Nilai Tertinggi } & \multicolumn{6}{|c|}{95} \\
\hline \multicolumn{2}{|c|}{ Nilai Terrendah } & \multicolumn{6}{|c|}{65} \\
\hline \multicolumn{2}{|c|}{ Nilai Rata-rata } & \multicolumn{6}{|c|}{81,88} \\
\hline \multicolumn{2}{|c|}{ Ketuntasan } & \multicolumn{6}{|c|}{$\mathbf{8 8 , 8 9}$} \\
\hline
\end{tabular}

Dari tabel di atas tentang peningkatan hasil belajar siswa dapat diterangkan sebagai berikut bahwa nilai rata-rata hasil belajar pada pelaksanaan perbaikan pembelajaran siklus pertama sebesar 72,88. Jumlah siswa yang tuntas belajarnya sebanyak 8 siswa atau sebesar $88,88 \%$, dan masih ada 1 siswa yang belum tuntas belajarnya atau sebesar $11,11 \%$. Dari penjelasan sebagaimana tersebut di atas dapat disimpulkan bahwa hasil nilai tes formatif mengalami peningkatan dari siklus I, karena pada siklus I siswa tuntas 5 siswa $(55,55 \%)$ meningkat menjadi 8 siswa $(88,88 \%)$ atau meningkat sebanyak 3 siswa $(33,33 \%)$. 


\section{Observasi}

Observasi dilaksanakan oleh peneliti dan observer (teman sejawat) pada saat melaksanakan kegiatan belajar mengajar dengan menggunakan lembar observasi yang telah disiapkan. Hasil observasi menunjukkan bahwa pelaksanaan pembelajaran berjalan dengan baik, penguasaan konsep dan materi pembelajaran siswa sudah maksimal. Hal ini dibuktikan dengan nilai tes formatif an peningkatan motivasi belajar siswa. Penjelasan mengenai aspek motivasi belajar yang diamati adalah kuatnya kemauan untuk berbuat, jumlah waktu yang disediakan untuk belajar, kerelaan meninggalkan kewajiban atau tugas yang lain, ketekunan dalam mengerjakan tugas, ulet menghadapi kesulitan (tidak lekas putus asa, menunjukkan minat terhadap bermacam- macam masalah orang, lebih senang bekerja mandiri, dapat mempertahankan pendapatnya, cepat bosan pada tugas-tugas rutin (Sardiman, 2001: 81). Kegiatan pengamatan ini dilakukan oleh observer selama kegiatan perbaikan pembelajaran berlangsung dengan menggunakan format observasi yang telah dipersiapkan. Hasil observasi pada pelaksanaan perbaikan pembelajaran pada siklus I sebagaimana tabel di bawah ini.

Tabel 4. Rekapitulasi Hasil Observasi Peningkatan Motivasi Siswa Pembelajaran Bahasa Indonesia Pada Siklus II

\begin{tabular}{c|cccc}
\hline No & Rentang Nilai & Jumlah & Persentase & Ket \\
\hline 1 & $90-100$ & 2 & 22,22 & $\mathrm{~T}$ \\
2 & $80-89$ & 3 & 33,33 & $\mathrm{~T}$ \\
3 & $70-79$ & 3 & 33,33 & $\mathrm{~T}$ \\
4 & $60-69$ & 1 & 11,11 & $\mathrm{BT}$ \\
5 & $<=50$ & 0 & 0,00 & $\mathrm{BT}$ \\
\hline
\end{tabular}

Dari tabel di atas dapat disimpulkan bahwa dari 9 siswa terdapat 8 orang yang tuntas belajarnya $(88,88 \%)$ dilihat dari motivasi belajarnya. Melihat hasil di atas maka peneliti bersama-sama dengan observer menyimpulkan bahwa hasil pengamatan terhadap peningkatan motivasi belajar sudah mencapai angka di atas $85 \%$, sehingga proses perbaikan pembelajaran dinyatakan berhasil dan tuntas pada siklus II.

\section{Refleksi}

Hampir semua tujuan telah tercapai sesuai dengan kriteria keberhasilan yang ditentukan.Berdasarkan hasil pengolahan data-data dan hasil observasi dilakukan analisis dan dapat diketahui bahwa semua tujuan telah tercapai sesuai dengan kriteria keberhasilan yang ditentukan. Melihat hasil proses pembelajaran dan peningkatan motivasi belajar siswa, maka dapat disimpulkan bahwa proses perbaikan pembelajaran Berhasil.

\section{Hasil Penelitian}

Penggunaan teknik membaca intensif sangat membantu dalam membangkitkan motivasi belajar siswa, ini terbukti dari hasil belajar yang diberikan pada setiap siklusnya mengalami peningkatan di mana pada siklus I nilai rata-rata yang diperoleh siswa adalah 72,88 dan pada siklus II rata-rata nilai yang diperoleh siswa adalah 81,88. Rekapitulasi nilai hasil tes formatif siswa dari kondisi awal, siklus I sampai dengan siklus II dapat dilihat dari tabel di bawah ini.

Tabel 5. Rekapitulasi Nilai Hasil Tes Formatif Temuan Awal, Siklus I dan Siklus II

\begin{tabular}{c|ccccccc}
\hline \multirow{2}{*}{ No } & & & \multicolumn{5}{c}{ Ketuntasan } \\
\cline { 5 - 7 } & Siklus & $\begin{array}{c}\text { Nilai } \\
\text { Rata-2 }\end{array}$ & T & \% & B & \% & Ket \\
\hline 1 & Awal & 56,99 & 2 & 22,22 & 7 & 77,78 & \\
\hline
\end{tabular}




\begin{tabular}{l|cccccc}
\hline 2 & Siklus I & 72,88 & 5 & 55,55 & 4 & 44,45 \\
3 & Siklus II & 74,11 & 8 & 88,88 & 1 & 11,11 \\
\hline
\end{tabular}

Dari tabel di atas dapat dijelaskan peningkatan nilai hasil dan ketuntasan belajar siswa pada siklus I dan II secara terperinci sebagai berikut :

1) Siswa Tuntas Belajar

a. Pada temuan awal siswa yang tuntas sebanyak 2 siswa $22,22 \%$ dari 9 siswa.

b. Pada siklus I siswa yang tuntas sebanyak 5 siswa atau $55,55 \%$ dari 9 siswa

c. Pada siklus II siswa yang tuntas sebanyak 8 siswa atau $88,88 \%$ dari 9 siswa

2) Siswa Belum Tuntas Belajar

a. Pada temuan awal siswa yang belum tuntas sebanyak 7 siswa atau $77,78 \%$ dari 9 siswa.

b. Pada siklus I siswa yang belum tuntas sebanyak 4 siswa atau 44,45\% dari 9 siswa

c. Pada siklus II siswa yang belum tuntas sebanyak 1 siswa atau $11,11 \%$ dari 9 siswa

Sesuai dengan kriteria keberhasilan yang telah ditetapkan dalam perbaikan pembelajaran bahwa siswa yang dinyatakan tuntas belajar jika mendapat nilai tes formatif sebesar $70 \mathrm{ke}$ atas dan jika $85 \%$ dari siswa telah tuntas belajarnya. Penjelasan mengenai peningkatan nilai rata-rata hasil belajar pada pembelajaran Bahasa Indonesia materi menemukan pokok pikiran teks bacaan dengan menggunakan teknik membaca intensif menunjukkan peningkatan yang cukup signifikan di mana pada kondisi awal sebesar 56,99 meningkat menjadi 77,78 pada siklus I dan pada akhir siklus II meningkat menjadi 88,88 . Hasil observasi pada pelaksanaan kegiatan perbaikan pembelajaran menunjukkan hasil yang positif, dan dibuktikan dengan adanya peningkatan motivasi siswa pada setiap siklusnya. Secara rinci penjelasan mengenai peningkatan motivasi siswa dalam proses perbaikan pembelajaran sebagaimana tabel di bawah ini :

Tabel 6. Rekapitulasi Peningkatan Motivasi Siswa pada Siklus I dan Siklus II

\begin{tabular}{|c|c|c|c|c|c|c|}
\hline \multirow[b]{2}{*}{ No } & \multirow{2}{*}{ Siklus } & \multicolumn{4}{|c|}{ Ketuntasan } & \multirow[b]{2}{*}{ Ket } \\
\hline & & $\mathbf{T}$ & $\%$ & B & $\%$ & \\
\hline 1 & Awal & 2 & 22,22 & 7 & 77,78 & \\
\hline 2 & Siklus I & 5 & 55,55 & 4 & 44,45 & \\
\hline 3 & Siklus II & 8 & 88,88 & 1 & 11,11 & \\
\hline
\end{tabular}

Dari tabel di atas dapat dijelaskan tentang siswa yang tuntas dan belum tuntas dilihat dari motivasi belajarnya, yaitu pada temuan awal, siswa tuntas dilihat dari motivasi belajar sebanyak 2 siswa atau 22,22 \% dari 9 siswa, pada siklus I, siswa tuntas dilihat dari motivasi belajar sebanyak 5 siswa atau 55,55\% dari 9 siswa, dan pada siklus II, belum tuntas dilihat dari motivasi belajar sebanyak 9 siswa atau 100\% dari 9 siswa. Dari hasil observasi mengenai motivasi siswa tersebut berdasarkan kriteria keberhasilan perbaikan pembelajaran dapat disimpulkan bahwa proses perbaikan pembelajaran dinyatakan berhasil karena peningkatan motivasi siswa mencapai angka $100 \%$ dari $85 \%$ batasan minimal yang telah ditentukan pada kriteria keberhasilan proses perbaikan pembelajaran.

\section{Pembahasan}

Berdasarkan tindakan yang telah dilakukan terbukti mampu meningkatkan motivasi dan hasil belajar siswa pembelajaran bahasa Indonesia materi menentukan ide pokok paragraf yang didengar melalui penerapan teknik membaca intensif. Keberhasilan penerapan teknik membaca intensif dalam upaya meningkatkan motivasi dan hasil belajar siswa pembelajaran 
bahasa Indonesia materi menentukan ide pokok paragraf yang didengar dapat dilihat dari indikator-indikator sebagai berikut:

\section{1) Motivasi Belajar Siswa}

Data motivasi siswa diperoleh dari lembar observasi yang telah diisi oleh observer selama perbaikan pembelajaran berlangsung. Fokus observasi difokuskan pada aspek-aspek kuatnya kemauan untuk berbuat, jumlah waktu yang disediakan untuk belajar, kerelaan meninggalkan kewajiban atau tugas yang lain, ketekunan dalam mengerjakan tugas, ulet menghadapi kesulitan (tidak lekas putus asa, menunjukkan minat terhadap bermacammacam masalah orang, lebih senang bekerja mandiri, dapat mempertahankan pendapatnya, cepat bosan pada tugas-tugas rutin (Sardiman, 2001).

Dari hasil analisi data hasil penelitian dapat dijelaskan tentang siswa yang tuntas dan belum tuntas dilihat dari motivasi belajarnya, yaitu pada temuan awal, siswa tuntas dilihat dari motivasi belajar sebanyak 2 siswa atau 22,22\% dari 9 siswa, pada siklus I, siswa tuntas dilihat dari motivasi belajar sebanyak 5 siswa atau 55,55\% dari 9 siswa, dan pada siklus II, belum tuntas dilihat dari motivasi belajar sebanyak 9 siswa atau 100\% dari 9 siswa.

Hasil yang diperoleh menunjukkan bahwa penerapan teknik membaca intensif berjalan dengan sangat baik sebagai salah satu upaya meningkatkan motivasi dan hasil belajar siswa dalam pembelajaran bahasa Indonesia materi menentukan ide pokok paragraf yang didengar. Dari siklus I ke siklus berikutnya mengalami peningkatan yang signifikan. Motivasi dan hasil belajar siswa mengalami peningkatan. Siswa dapat menentukan ide pokok paragraf yang didengar melalui penerapan teknik membaca intensif lebih mudah.

Keberhasilan proses perbaikan pembelajaran tidak hanya dilihat dari peningkatan hasil belajar atau nilai tes formatif saja. Motivasi belajar siswa selama proses pembelajaran juga merupakan indikator keberhasilan dalam proses pembelajaran. Data motivasi siswa diperoleh dari lembar observasi yang telah diisi oleh observer selama perbaikan pembelajaran berlangsung. Dengan diterapkannya teknik membaca intensif membuat siswa menjadi lebih semangat dalam belajar. Siswa yang kemampuannya masih rendah dapat terbantu dengan adanya variasi dalam pembelajaran bahasa Indonesia. Dengan demikian tercipta suasana belajar yang menyenangkan dan bermakna yang selanjutnya akan meningkatkan kemampuan menentukan ide pokok paragraf yang didengar melalui penerapan teknik membaca intensif.

\section{2) Hasil Belajar Siswa}

Berdasarkan hasil penelitian tentang peningkatan kemampuan menentukan ide pokok paragraf yang didengar melalui teknik membaca intensif pada mata pelajaran Bahasa Indonesia di kelas V SDN Bambalo , maka didapatkan rata-rata kelas pada kondisi awal sebesar 56,99 dengan jumlah siswa tuntas sebanyak 2 siswa atau 22,22\%, pada siklus I dengan skor 72,88 . Siswa yang tuntas pada pembelajaran siklus I yaitu sebanyak 5 siswa dari 55,55 siswa atau sebesar 44,45 \%. Hal tersebut dikarenakan siswa kurang aktif dalam berdiskusi dan kurang memperhatikan pelajaran sehingga nilai yang diperoleh siswa masih sedikit jauh dari KKM yang diharapkan yaitu 70. Pada perbaikan siklus II, siswa mulai paham dengan penerapan teknik membaca intensif, sehingga hasil nilai siswa meningkat dan sudah mencapai KKM. Hal ini dapat dilihat dari kenaikan nilai rata-rata kelas pada siklus II yaitu 74,11 dengan jumlah siswa yang tuntas yaitu 8 siswa dari 9 siswa atau sebesar 88,89\%.

Pemaparan di atas menunjukkan bahwa penerapan teknik membaca intensif dapat meningkatkan motivasi dan hasil belajar siswa dan siswa menjadi lebih aktif dalam kegiatan pembelajaran. Siswa dapat mencapai KKM dalam mata pelajaran bahasa indonesia materi menentukan ide pokok paragraf yang didengar. Dari penelitian yang sudah dilaksanakan dapat diketahui bahwa penelitian telah mengalami keberhasilan. 
Atas dasar pertimbangan sebagaimana diurakan di atas, maka peneliti dan observer sepakat memutuskan bahwa kegiatan perbaikan pembelajaran diakhiri pada siklus II. Berdasarkan data-data hasil pelaksanaan perbaikan pembelajaran sebagaimana diuraikan di atas berupa data hasil tes formatif siklus I, tes formatif siklus II dan data hasil observasi siklus I dan II maka dapat disimpulkan bahwa penggunaan teknik membaca intensif dapat meningkatkan hasil belajar dan motivasi siswa pada pembelajaran Bahasa Indonesia menentukan ide pokok paragraf dengan teknik membaca intensif pada siswa kelas V SDN Bambalo semester 1 Tahun Pelajaran 2020/2021.

\section{Kesimpulan}

Penggunaan teknik membaca intensif pada pembelajaran Bahasa Indonesia materi penemuan gagasan utama teks mampu meningkatkan motivasi dan hasil belajar siswa. Hal ini dikarenakan pembelajaran dilaksanakan dengan kegiatan praktik langsung tidak hanya sebatas teori saja sehingga pemahaman siswa terhadap materi pembelajaran menjadi lebih baik. Pengaturan kelompok belajar adalah sebagai bagian dari metode untuk meransang siswa dalam suasana kelas yang berbeda, sehingga terjadi pembelajaran yang lebih menarik. Saling berinteraksi saat siswa memaparkan atau hasil kerjanya dalam materi penemuan gagasan utama teks yang dibacanya. Hal inilah yang akan membangkitkan motivasi dan hasil belajar siswa dalam pelaksanaan proses pembelajaran. Berdasarkan hasil diskusi, data dan hasil temuan dapat ditarik kesimpulan bahwa : (1) Peningkatan motivasi belajar semakin membaik, pada studi awal siswa tuntas dilihat dari motivasi belajar sebanyak 2 siswa atau 22,22\% dari 9 siswa, pada siklus I, siswa tuntas dilihat dari motivasi belajar sebanyak 5 siswa atau 55,55\% dari 9 siswa, dan pada siklus II, belum tuntas dilihat dari motivasi belajar sebanyak 9 siswa atau $100 \%$ dari 9 siswa. (2) Kenyataan di atas didukung dengan perolehan nilai yang semakin meningkat pada setiap siklusnya. Nilai rata-rata kelas semakin meningkat dari 56,99 pada studi awal, menjadi 72,88 pada siklus I, dan pada siklus II menjadi 81,88 dengan tingkat ketuntasan belajar dari 2 siswa atau 22,22\% pada kondisi awal menjadi 5 siswa atau $55,55 \%$ pada siklus pertama dan 8 siswa atau $88,88 \%$ pada siklus kedua.

\section{Saran}

Adapun saran yang dapat disampaikan berdasarkan hasil penelitian ini adalah bagi Siswa; (1) hendaknya lebih aktif dalam mengikuti pembelajaran, lebih bertanya dalam bertanya kepada guru, memberikan tanggapan dan saran terhadap hasil diskusi sehingga hasil dan proses pembelajaran dapat berjalan secara maksimal. (2) Siswa hendaknya lebih rajin membaca dengan memanfaatkan fasilitas perpustakaan yang ada di sekolah. Bagi Guru; (1) hendaknya menguasai berbagai pendekatan pembelajaran yang tepat untuk membelajari siswa agar berhasil memenuhi tuntutan pembelajaran, baik proses maupun hasil sehingga keberhasilan pembelajaran dapat tercapai, salah satu dari pendekatan pembelajaran adalah pendekatan kompetensi. (2) Guru hendaknya memberikan bimbingan dan arahan yang tepat serta mudah diikuti oleh siswa, khususnya pada saat siswa menempuh langkah-langkah belajar berdasarkan pendekatan kompetensi. Hal ini penting mengingat pada saat proses belajar sedang berlangsung potensi (kemampuan) siswa akan berkembang apabila guru melakukan upaya-upaya yang tepat untuk mengembangkannya. (3) Untuk meningkatkan profesionalisme guru, salah satu upaya yang dapat ditempuh adalah melalui upaya perbaikan pembelajaran atau penelitian tindakan kelas (PTK) tidak hanya pada mata pelajaran matematika saja, tetapi dapat pula diterapkan pada mata pelajaran yang lain agar keberhasilan siswa dalam proses pembelajaran dapat tercapai secara maksimal. Bagi Sekolah; sebaiknya 
memperhatikan sarana dan prasana di sekolah yang dibutuhkan siswa maupun guru, karena dengan sarana dan prasana yang lengkap akan menciptakan suasana yang baik dalam proses pembelajaran.

\section{Daftar Pustaka}

Arikunto, S. (2007). Dasar-Dasar Evaluasi Pendidikan. Jakarta : Bumi Aksara

Cahyani, I (2007). Kemampuan Berbahasa Indonesia di Sekolah Dasar. Bandung : UPI Press Ismoyo. 2008. Aku Bangga Bahasa Indonesia 5. Jakarta : Depdiknas

Mahartati, I. (2017). Meningkatkan Motivasi dan Hasil Belajar Tematik Peserta Didik dengan Mengoptimalkan Penerapan Model Discovery Learning di SD Negeri 3 Cakranegara. Jurnal Kependidikan: Jurnal Hasil Penelitian dan Kajian Kepustakaan di Bidang Pendidikan, Pengajaran dan Pembelajaran, 3(2). doi:https://doi.org/10.33394/jk.v3i2.568

Mulyati, Yeti dkk. (2007). Keterampilan Berbahasa Indonesia SD. Jakarta : Universitas Terbuka.

Nurmala, S. (2020). Menerapkan Model Reading Guide Berbasis Paikem dalam Upaya Meningkatkan Motivasi Belajar Peserta Didik Kelas VI SD Negeri 27 Ampenan. Jurnal Paedagogy, 6(2), 34-40. doi:https://doi.org/10.33394/jp.v6i2.2529

Nurmiati, B. (2020). Meningkatkan Motivasi dan Hasil Belajar Peserta Didik dengan Mengoptimalkan Penerapan Model Discovery Learning di SD Negeri 2 $\begin{array}{llll}\text { Cakranegara. Jurnal Paedagogy, } & 6(1),\end{array}$ doi:https://doi.org/10.33394/jp.v6i1.2523

Rahim, Farida. (2008). Pengajaran Membaca di Sekolah Dasar. Jakarta : Bumi Aksara.

Resmini, Novi dkk. (2009). Pembinaan dan Pengembangan Pembelajaran Bahasa dan Sastra Indonesia. Bandung : UPI Press.

Setiarini, A. (2016). Meningkatkan Motivasi dan Hasil Belajar Peserta Didik dengan Mengoptimalkan Penerapan Pendekatan Saintifik Strategi Discovery Learning dan Metode Diskusi di SDN Model Mataram. Jurnal Kependidikan: Jurnal Hasil Penelitian dan Kajian Kepustakaan di Bidang Pendidikan, Pengajaran dan Pembelajaran, 2(1). doi:https://doi.org/10.33394/jk.v2i1.390

Suarni, G., Rizka, M., \& Zinnurain, Z. (2021). Analisis Pengaruh Penerapan Model Pembelajaran Sains Teknologi Masyarakat Terhadap Hasil Belajar Siswa. Jurnal Paedagogy, 8(1), 31-38. doi:https://doi.org/10.33394/jp.v8i1.3226

Tarigan, HG (2008). Membaca Sebagai Suatu Keterampilan Berbahasa. Bandung : Angkasa.

Wardani, Julaeha. S, dan Marsinah, (2005). Pemantapan Kemampuan Profesional (Panduan). Pusat Penerbitan Universitas Terbuka. 